\title{
The Dilemma of Choroidal Fissure Cyst and Seizure
}

\section{Editorial}

Journal of Epilepsy Research pISSN 2233-6249 / EISSN 2233-6257
Tariq Al-Saadi, MD ${ }^{1,2}$

${ }^{1}$ Department of Neurology \& Neurosurgery, Faculty of Medicine, McGill University, Montreal, Canada; ${ }^{2}$ Department of Neurosurgery, Khoula Hospital, Muscat, Sultanate of Oman
Choroidal fissure cyst (CFC) is a rare embryological entity presenting as cerebrospinal fluid (CSF) containing cysts at the level of the choroidal fissure. The literature is lacking articles discussing this topic, with only case few reports and series. ${ }^{1-3}$ There are several theories exist to explain the mechanism of primary choroidal cysts development: 1) as a result of aberrant splitting and duplication in the arachnoid membrane as proposed by Starkman et al. ${ }^{2}$ and Krawchenko and Collins, ${ }^{4} 2$ ) in response to temporal lobe agenesis, resulting in forming a cyst in the subarachnoid space, ${ }^{5}$ and 3) from invagination of the vascular mesenchyme of the primitive choroid plexus into adjacent brain picked up an outer covering of glial tissue. ${ }^{6}$

Computed tomography (CT) and magnetic resonance imaging
(MRI) are used to differentiate between the CFC and other differential diagnoses of cysts located at the choroidal fissures including cystic neoplasm, dermoid/epidermoid cysts, and enlargement of the choroidal fissure due to focal temporal lobe atrophy. ${ }^{1} \mathrm{CT}$ scans show a well-delineated homogeneous low-density mass with attenuation characteristics similar to CSF without calcification or contrast enhancement. MRI signal characteristics are similar to CSF on all sequences. The cyst walls are thin and contrast enhancement, surrounding edema, and gliosis are absent. ${ }^{7}$ The coronal images are better to identify the relation between the cyst and the choroidal fissure. ${ }^{1}$ The final diagnosis can only be made by histopathological examination. The cysts are usually small asymptomatic and dis-

Table 1. Summary of patients with choroid fissure cysts in the literature

\begin{tabular}{|c|c|c|c|c|c|c|c|c|c|}
\hline No. & Study & Article type & Journal & $\begin{array}{c}\text { No. of } \\
\text { patients } \\
\text { with CFC }\end{array}$ & Gender & $\begin{array}{c}\text { Mean age at } \\
\text { diagnosis } \\
\text { (years) }\end{array}$ & $\begin{array}{l}\text { Site of the } \\
\text { CCF cyst }\end{array}$ & $\begin{array}{l}\text { Presenting } \\
\text { symptoms }\end{array}$ & Treatment \\
\hline 1 & $\begin{array}{l}\text { De Jong et al. }{ }^{3} \\
(2011)\end{array}$ & $\begin{array}{l}\text { Peer-review } \\
\text { reports }\end{array}$ & $\begin{array}{l}\text { World } \\
\text { Neurosurgery }\end{array}$ & 6 & - & 8.9 & $\begin{array}{l}\text { Rt: } 5 \\
\text { Lt: } 1\end{array}$ & $\begin{array}{l}\text { Headache: } 3 \text { cases } \\
\text { Narcolepsy: } 1 \\
\text { ADHD: } 1 \\
\text { Spastic spasm: } 1\end{array}$ & $\begin{array}{l}\text { Conservative } \\
\text { management }\end{array}$ \\
\hline 2 & $\begin{array}{l}\text { Isolan et al. }{ }^{11} \\
(2010)\end{array}$ & Case report & $\begin{array}{l}\text { J Epilepsy Clin } \\
\text { Neurophysiol }\end{array}$ & 2 & $\begin{array}{c}\text { M: } 1 \\
\mathrm{~F}: 1\end{array}$ & 19.5 & Lt: 2 & Seizure CP: 2 & $\begin{array}{l}\text { Conservative } \\
\text { management }\end{array}$ \\
\hline 3 & $\begin{array}{l}\text { Arroyo and } \\
\text { Santamaria }^{9} \\
(1997)\end{array}$ & $\begin{array}{l}\text { Retrospective } \\
\text { study }\end{array}$ & Epilepsin & 9 & - & 31 & $\begin{array}{l}\text { Rt: } 6 \\
\text { Lt: } 3\end{array}$ & Seizure: 8 CP, 1 GTC & NM \\
\hline 4 & Millichap ${ }^{10}$ (1997) & Case series & Neurology & 1 & M: 1 & 4 & Lt: 1 & ADHD/headache & $\begin{array}{l}\text { Conservative } \\
\text { management }\end{array}$ \\
\hline 5 & $\begin{array}{l}\text { Morioka et al. }{ }^{12} \\
(1994)\end{array}$ & Case report & $\begin{array}{l}\text { Clinical } \\
\text { Neurology and } \\
\text { Neurosurgery }\end{array}$ & 2 & $\begin{array}{c}\text { M: } 1 \\
\mathrm{~F}: 1\end{array}$ & 25 & $\begin{array}{l}\text { Rt: } 1 \\
\text { Lt: } 1\end{array}$ & Seizure CP: 2 & $\begin{array}{l}\text { Conservative } \\
\text { management }\end{array}$ \\
\hline
\end{tabular}

CFC, choroidal fissure cyst; CCF, choroidal fissure cyst; Rt, right; Lt, left; ADHD, attention deficit hyperactivity disorder; $M$, male; F, female; $\mathrm{CP}$, complex partial; GTC, generalized tonic-clonic; NM, not mentioned.

Received June 14, 2020 / Revised June 19, 2020 / Accepted July 28, 2020

Corresponding author: Tariq Al-Saadi, MD

Department of Neurology \& Neurosurgery, Faculty of Medicine, McGill University, 3801 Rue University, Montreal, Quebec H3A 2B4, Canada

Tel. +1-438-405-9099, Fax. +1-514-332-0021, E-mail; t.dhiyab@hotmail.com

This is an Open Access article distributed under the terms of the Creative Commons Attribution Non-Commercial License (http://creativecommons.org/licenses/by-nc/3.0/) which permits unrestricted non-commercial use, distribution, and reproduction in any medium, provided the original work is properly cited. 
covered incidentally. Very rarely, they may cause seizures due to the mass effect on the temporal lobe. ${ }^{8}$

A literature review of this topic was conducted by searching human, English-language publications in MED-LINE (PubMed and Ovid), Google Scholar, and Cochrane Library from January 1, 1950 to June 9, 2020.

Table 1 shows the total cases of CFC mentioned in the literature. The current review showed 20 cases reported in the literature (Table 1). The right side was more common (60\%) and seizure was the main presenting symptom in 13 cases (65\%). The type of treatment was mentioned in 11 cases and all were managed conservatively. However, no information was available in the remaining nine cases. In the Sherman series, ${ }^{1} 26$ patients had cysts in or near the choroidal fissure of the temporal lobe, and it was bilateral in two patients. The report described five patients with a seizure disorder, none of them electroencephalographically correlated to the cyst location as the epileptogenic cortex usually was not adjacent to the patient's cyst. ${ }^{1}$

Arroyo and Santamaria ${ }^{9}$ describe a series of 17 patients with epilepsy and an arachnoid cyst. Of which, nine were having CFCs. The authors suggested that these cysts are often incidental findings and do not necessarily reflect the location of the seizure focus. Millichap ${ }^{10}$ describes three patients with a temporal arachnoid cyst, one of them being a CFC, presenting with attention deficit hyperactivity disorder and headache. The author recommended neuropsychological tests for associated attention and learning deficits which might be observed in cases with CFCs.

CFCs are embryological lesions that are rarely described in the literature due to their benign nature and tendency to be asymptomatic. The CFCs do not always reflect the location of the seizure focus. In all the cases reported in the literature, surgical treatment was not considered. Follow-up with regular imaging will is suggested. However, the frequency of these surveillance scans and when follow-up can be stopped is still unknown.

\section{Conflict of Interest}

The author declares that they have no conflicts of interest.

\section{References}

1. Sherman JL, Camponovo E, Citrin CM. MR imaging of CSF-like choroidal fissure and parenchymal cysts of the brain. AJNR Am J Neuroradio 1990; 11:939-45.

2. Starkman SP, Brown TC, Linell EA. Cerebral arachnoid cysts. J Neuropathol Exp Neurol 1958;17:484-500.

3. De Jong L, Thewissen L, van Loon J, Van Calenbergh F. Choroidal fissure cerebrospinal fluid-containing cysts: case series, anatomical consideration, and review of the literature. World Neurosurg 2011;75:704-8.

4. Krawchenko J, Collins GH. Pathology of an arachnoid cyst. J Neurosurg 1979;50:224-8.

5. Robinson RG. Congenital cysts of the brain: arachnoid malformations. Prog Neurol Surg 1971;4:133-74.

6. Yeates A, Enzmann D. An intraventricular arachnoid cyst. J Comput Assist Tomogr 1979;3:697-700.

7. EL-Feky M, Weerakkody Y. Choroidal fissure cyst [Internet]. Australia: Radiopaedia, [cited 2020 Jun 10]. Available at: https://radiopaedia.org/ articles/choroidal-fissure-cyst-1.

8. Runge VM, Morelli JN. Essentials of Clinical MR. New York: Thieme Medical Publishers, Inc., 2010.

9. Arroyo S, Santamaria J. What is the relationship between arachnoid cysts and seizure foci? Epilepsia 1997;38:1098-102.

10. Millichap JG. Temporal lobe arachnoid cyst-attention deficit disorder syndrome: role of the electroencephalogram in diagnosis. Neurology 1997;48:1435-9.

11. Isolan GR, Bianchin MM, Torres CM, et al. Temporal choroidal fissure cyst and temporal lobe epilepsy: report of two cases. J Epilepsy Clin Neurophysiol 2010;16:167-9.

12. Morioka T, Nishio S, Suzuki S, Fukui M, Nishiyama T. Choroidal fissure cyst in the temporal horn associated with complex partial seizure. Clin Neurol Neurosurg 1994;96:164-7. 